\title{
Application of Ultrasound-Assisted Extraction on the Stem Bark of Rhinachantus Nasutus (L.) Kurz, Total Phenolic, and Its Potential as Antioxidant and Inhibitor of Alpha-Glucosidase Enzyme Activity
}

\author{
Candra Irawan ${ }^{1,2}$, Berna Elya ${ }^{1, *}$, Muhammad Hanafi ${ }^{3}$, Fadlina Chany Saputri ${ }^{1}$
}

\section{Candra Irawan ${ }^{1,2}$, Berna Elya ${ }^{1, *}$, Muhammad Hanafi ${ }^{3}$, Fadlina \\ Chany Saputri ${ }^{1}$}

'Faculty of Pharmacy Universitas Indonesia, Depok 16424, West Java, INDONESIA. ${ }^{2}$ Department of Analytical Chemistry; Politeknik AKA Bogor; Bogor 16154; INDONESIA. ${ }^{3}$ Research Center for Chemistry, Indonesian Institute of Science, Serpong (LIPI Indonesia) INDONESIA.

\section{Correspondence}

Berna Elya

Faculty of Pharmacy Universitas Indonesia

Depok 16424, West Java, INDONESIA.

E-mail id: berna.elya@farmasi.ui.ac.id

History

- Submission Date: 13-06-2021;

- Review completed: 22-07-2021;

- Accepted Date: 30-07-2021.

DOI : 10.5530/pj.2021.13.164

Article Available online

http://www.phcogj.com/v13/i5

Copyright

(C) 2021 Phcogj.Com. This is an openaccess article distributed under the term of the Creative Commons Attribution 4.0 International license.

\begin{abstract}
Aims: This study aims to obtain a stem bark extract of Rhinachantus nasutus (L.) Kurz through the application of ultrasound-assisted extraction (UAE) and reveal: the total phenolic content in the extract; The extract's potential as an antioxidant with copper-reducing strength parameters, and its potential as an antidiabetic by inhibiting alpha-glucosidase activity. Results: The crude ethanol extract of $R$. nasutus stem bark obtained from the UAE process was $7.4896 \mathrm{~g}$ with a yield of $4.99 \%$. The high total phenolic content, namely $677.3343 \pm 0.0007 \mathrm{mg} \mathrm{GAE} / \mathrm{g}$ sample, the antioxidant activity test using the CUPRAC method gave an $\mathrm{IC}_{50}$ value of $18.43 \pm 0.20 \mathrm{mg} / \mathrm{L}$. In addition, the ethanol extract of stem bark has a high ability to inhibit the activity of the alpha-glucosidase enzyme with an $I_{50}$ value of $10.95 \pm 0.28 \mathrm{mg} / \mathrm{L}$. Conclusion: The ethanol extract of the stem bark of $R$. nasutus from UAE has the potential as a source of antioxidants and antidiabetic.

Key words: Alpha-glucosidase enzyme, Antidiabetic, Antioxidant, Rhinachantus nasutus (L.) Kurz, Total phenolics content, Ultrasound-assisted extraction.
\end{abstract}

\section{INTRODUCTION}

Medicinal plants play a significant role in human health. This is related to the content of chemical compounds in medicinal plants, which can produce physiological effects on the human body. Today, traditional medicine derived from various medicinal plants is widely studied and used as the basis for finding new compounds to treat multiple diseases. Important bioactive compounds in plants are phenolic compounds, alkaloids, tannins, and flavonoids ${ }^{1}$.

The World Health Organization (WHO) reports that the number of people with diabetes mellitus increases every year. In 2014, the percentage of people with diabetes mellitus in adults worldwide was $8.5 \%$ or 422 million sufferers ${ }^{2}$, and it is predicted that it will be 700 million by $2045^{3}$. Diabetes is a metabolic disease characterized by an uncontrolled increase in glucose levels in the blood (hyperglechemicals). This occurs due to impaired insulin secretion, insulin action, or both. Other factors are genetics, age, and obesity. The chronic hyperglycemic state of diabetes is associated with long-term damage, impaired function, and various organs' failure, especially the eye; kidney; nerve; heart; and blood vessels ${ }^{4,5}$.

Several alpha-glucosidase inhibitors, such as acarbose, have been used clinically to treat diabetes ${ }^{6}$. This medicine may cause side effects such as flatulence, stomach cramps, vomiting, and diarrhoea. Therefore, it is necessary to find alternative drugs that can inhibit alpha-glucosidase activity without side effects ${ }^{7}$. Various studies have been conducted to identify natural sources that can inhibit alpha-glucosidase activity. Natural ingredients such as cereals, Pometia pinnata, strawberries, blueberries, broccoli sprouts, and protein in egg whites have been reported to exhibit alpha-glucosidase inhibitory activity ${ }^{8,9,10}$.

Rhinacanthus nasutus (L.) Kurz is a flowering plant in the acanthaceae family spread across Southeast Asia, India and China ${ }^{11,12}$. R. nasutus is known by various names, such as Snake Jasmine, Rangchita Dainty, Spurs, Palakjuhi, Juhipani, Gajkarni, Uragamalli, Nagamalli, Nagamulla, Puzhukkolli, Nagamalle, Nagamallige, Doddapatike, Juipana, Dadmari, Palakjuhi, and Yudhikaparni ${ }^{12}$. Another name is Bai He Ling Zhi in China ${ }^{13}$, Thong-panchung in Thailand ${ }^{14}$, while in Indonesia it is known as "Manukan" and Cengkerang is used by the people of Menggala, Kabupaten Tulang Bawang, Lampung. Roots, stems, and leaves of $R$. nasutus are used in traditional medicine such as diabetes eczema, eczema, scabies, leprosy, herpes, pulmonary tuberculosis, hepatitis, hypertension, and obesity ${ }^{15}$. $R$. nasutus leaf extract has been reported to have more significant alpha-glucosidase inhibition activity than acarbose ${ }^{16}$. It has never been previously reported regarding alpha-glucosidase inhibiting activity from the bark of $R$. nasutus.

A crucial first step in the study of medicinal plants is selecting an extraction method to obtain plant extracts. One of the most widely used extraction methods is maceration. This method's weakness is that it requires a long extraction time and the use of large amounts of solvent ${ }^{17}$. Maceration using hexane, ethyl acetate, methanol, and distilled water was 
carried out on the dried powder of the leaves of $R$. nasutus ${ }^{18}$. Various extraction techniques have been developed to obtain methods that are more environmentally friendly, reduce solvent use, prevent possible degradation of compounds due to heat use, shorten extraction times, increase reaction rates, and increase the yield and quality of extracts ${ }^{19}$. One of them is the sonification method using ultrasonic ${ }^{20,21}$.

The use of ultrasonic waves passed in the solvent will cause a cavitation effect which gives a mechanical effect, thus allowing greater penetration of the solvent into the sample matrix, increasing the contact surface area between the solid and liquid phases. As a result, the solute quickly diffuses from the solid phase to the solvent ${ }^{21}$. In this method, no chemicals can prevent the possibility of chemical degradation of the targeted compounds ${ }^{19}$. The use of the UAE extraction method on the bark of $R$. nasutus has not been previously reported.

\section{METHODS}

\section{Simplicia setup}

The plants used were previously determined by the correctness of identity in the Herbarium Bogoriense, Botany field of the Indonesian Institute of Sciences Biology Research Center, Cibinong, Bogor Regency, West Java. The stem bark samples of $R$. nasutus (Figure 1) were obtained from the researchers' private plants planted in Bogor. The bark that is sampled is one year old. The stems were washed with water, and then the bark was collected and dried in the open air without sunlight for two weeks. Simplicia was weighed and mashed using a blender and sieved with a 40-mesh sieve. Simplicia powder is stored separately in dry, closed, identified containers and protected from direct sunlight until extraction is carried out.

\section{Extraction of Simplicia}

The simplicia powder of the stem bark of $R$. nasutus was weighed as much as $150 \mathrm{~g}$, then $500 \mathrm{~mL}$ of $70 \%$ ethanol solvent was added. The mixture was sonicated using a vibrating ultrasonic probe for 30 minutes at room temperature with an amplitude of $0.6 \mathrm{~m}$. The extract without the solvent was weighed, and the percent yield was calculated.

\section{Total Phenolic}

The total phenolic content of the extract was determined by the Folin - Ciocalteu method ${ }^{22}$. Briefly $400 \mu \mathrm{L}$ of crude extract $(1 \mathrm{mg} / \mathrm{mL})$ that were made up to $6 \mathrm{~mL}$ with distilled water, mixed thoroughly with 1 $\mathrm{mL}$ of Folin - Ciocalteu reagent for $3 \mathrm{~min}$, followed by the addition

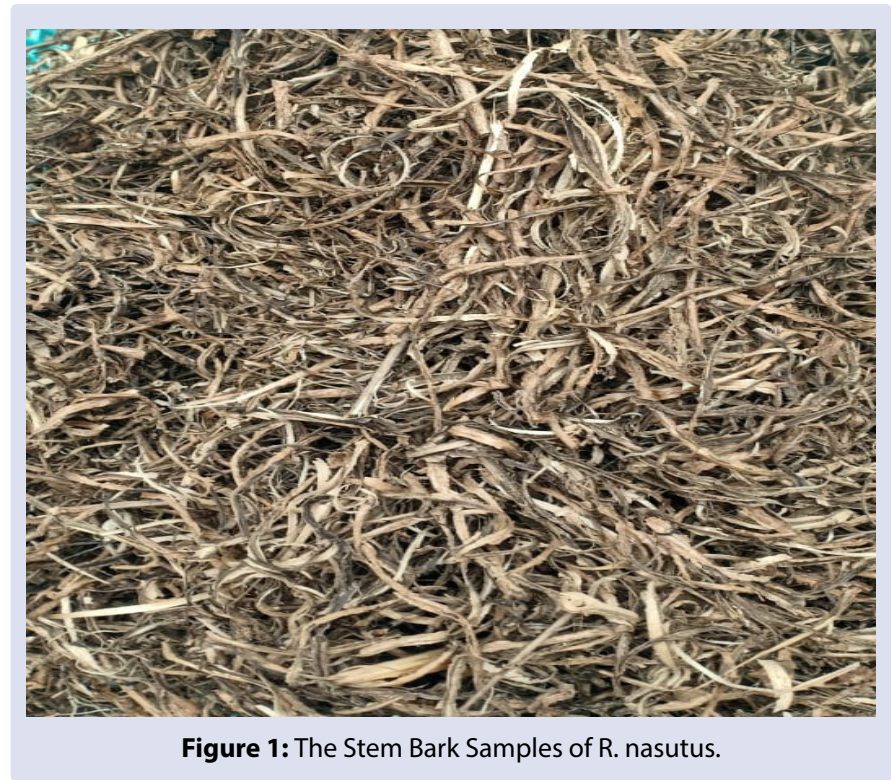

of $2,5 \mathrm{~mL}$ of $10 \%$ (w/v) sodium carbonate, measured with distilled water in a $10 \mathrm{~mL}$ measuring flask, then homogenized. The mixture was allowed to stand for a further $60 \mathrm{~min}$ in the dark, and absorbance was measured at $650 \mathrm{~nm}$. The total phenolic content was calculated from gallic acid calibration curves (concentrations $0,4,6,8$, and $10 \mathrm{mg} /$ L). The results were expressed as mg of gallic acid equivalent per g dry weight.

\section{Antioxidant Activity Test of the Cupric lon Reducing Antioxidant Capacity (CUPRAC) Method}

A total of $5 \mathrm{mg}$ of stem bark extract was dissolved with methanol pa in a $5 \mathrm{~mL}$ measuring flask, resulting in a sample solution with a concentration of $1,000 \mathrm{mg} / \mathrm{L}$. Solution pipette $20 ; 40 ; 60 ; 80$; and 100 $\mu \mathrm{L}$, then each was put into five $5 \mathrm{~mL}$ measuring flasks, then added 1 $\mathrm{mL}$ of CUPRAC solution, then measured with methanol pa, and homogenized (sample concentrations 4, 8, 12, 16; and $20 \mathrm{mg} / \mathrm{L}$ ). The solution was incubated for 30 minutes at $37^{\circ} \mathrm{C}$, the absorption of the solution was measured using a visible light spectrophotometer at a wavelength of $459 \mathrm{~nm}^{23}$. The work is carried out in three repetitions. The same work is done for the BHT comparators by pipetting $1.25 ; 2.5$; and $3.75 \mu \mathrm{L}$ of BHT solution of $1,000 \mathrm{mg} / \mathrm{L}$ (BHT concentrations of $0.25 ; 0.5$; and $0.75 \mathrm{mg} / \mathrm{L}$ ). Reducing activity can be calculated with the following equation:

$\%$. Reduction Activity $=\frac{\left(A_{\text {sample }}-A_{\text {blank }}\right)}{A_{\text {sample }}} \times 100 \%$

Details :

$\mathrm{A}_{\text {blank }}=$ Absorbance without sample

$\mathrm{A}_{\text {Sample }}=$ Absorbance of sample

The calculated value is entered into a linear equation $(\mathrm{Y}=\mathrm{bX}+\mathrm{a})$ with the ppm concentration $(\mathrm{mg} / \mathrm{L})$ as the abscissa (X-axis) and the $\%$ value of the reduction as the ordinate (Y-axis). The $\mathrm{IC}_{50}$ value is obtained from the calculation when the $\%$ reduction is $50 \%$.

$$
\text { IC50 }=\frac{50-a}{b}
$$

\section{Alpha-Glucosidase Inhibitor Activity Test}

The alpha-glucosidase inhibition test was carried out on a blank solution (test solution without sample/standard), acarbose solution as a comparison standard (positive control), stem bark extract as a sample. The comparison standard and the stem bark ethanol extract sample were weighed and dissolved with a phosphate buffer $\mathrm{pH} 6.8$. Samples that were not dissolved with phosphate buffer were first dissolved with DMSO at a maximum of $10 \%$. The standard solution and sample were diluted into several concentrations. A total of $30 \mu \mathrm{L}$ of standard solution and $17 \mu \mathrm{L}$ of samples were added to the paraNitrofenil- $\alpha$-D-glucopyranoside (PNPG) substrate. The solution was incubated for 5 minutes at $37^{\circ} \mathrm{C}$, and $17 \mu \mathrm{L}$ of the alpha-glucosidase solution was added. The solution was incubated again at $37^{\circ} \mathrm{C}$ for 15 minutes, then added $100 \mu \mathrm{L}$ of $200 \mathrm{mM}$ sodium carbonate. The absorbance of the solution was measured with a microplate reader at $\lambda$ $405 \mathrm{~nm}^{24}$. The same procedure was carried out for the control test, but with a difference after the first incubation, $100 \mu \mathrm{L}$ of $200 \mathrm{mM}$ sodium carbonate was added first, and $17 \mu \mathrm{L}$ of the alpha-glucosidase solution was added after the second incubation. The absorbance of the solution was measured with a microplate reader at $\lambda 405 \mathrm{~nm}$.

\section{RESULT AND DISCUSSION}

\section{Ultrasonic-Assisted Extraction}

The extraction of $R$. nasutus stem bark was carried out by sonification method using an ultrasonic probe with ethanol solvent at $25^{\circ} \mathrm{C}$ and an amplitude of $0.6 \mathrm{~m}$ for 30 minutes. The irradiation cross-sectional area depends on the vibrating horn dye's depth and can be used to adjust 
the irradiation intensity. The ultrasonic configuration of this vibrating horn system can be used for the need to damage plant cell tissue, thereby increasing the ability of solvents to penetrate cells and produce higher extracts and an efficient process ${ }^{25,26}$. Table 1 shows the crude ethanol extract of $R$. nasutus skin of $7.4896 \mathrm{~g}$ with a yield of $4.99 \%$.

\section{Phenolic Content of Ethanol Extract}

Determination of total phenol levels in the stem bark of R. nasutus in this study using the Folin - Ciocalteu method. The Folin-Ciocalteu reagent contains phosphomolybdic acid and phosphotungstic acid, which phenolic compounds will reduce to form a bluish-purple complex molybdenum-tungsten combination ${ }^{27,28}$. Gallic acid is used as a standard because it is stable and is a derivative of hydroxybenzoic acid $^{29}$. The standard curve of gallic acid can be seen in Figure 2 with the linear regression equation $y=0.0996 x+0.0455$ and an $R 2$ value of 0.9829 . The total phenol content in the stem bark of $R$. nasutus obtained from this equation was $677.3343 \pm 0.0007 \mathrm{mg} \mathrm{GAE} / \mathrm{g}$ of the sample.

The total phenol in plants usually correlates with antioxidant activity. The higher the phenol content, the higher the antioxidant activity ${ }^{30}$. Phenolic compounds can donate protons to inhibit free radicals so that the radicals will become stable. This stable radical is formed due to resonance in the aromatic ring, which causes the delocalization of electrons ${ }^{31,32}$.

\section{Antioxidant Activity of the CUPRAC Method}

The CUPRAC method is a method for determining antioxidant activity based on single electron transfer $(\mathrm{SET})^{33}$. The reagent $\mathrm{Cu}$ (II) -neocuproin $\left(\mathrm{Cu}(\mathrm{II})-(\mathrm{Nc})_{2}\right)$ is used as an oxidizing agent. This method's principle is the reduction of $\mathrm{Cu}(\mathrm{Nc})_{2}{ }^{2+}$ reagents by antioxidants to form $\mathrm{Cu}(\mathrm{Nc})^{2+}$. The observation is that the colour changes from blue to

Table 1: Weight of Ethanol Extract and Yield Resulting from the UAE Process.

\begin{tabular}{lcc}
\hline Sample & Weight $(\mathrm{g})$ & Yield (\%) \\
\hline Dry sample & 150.000 & \\
Ethanolic Extract & 7.4896 & 4.99
\end{tabular}

Table 2: Antioxidant Activity Test Results of the CUPRAC Method.

\begin{tabular}{lccc}
\hline Sample & $\begin{array}{c}\text { Concentration } \\
(\mathrm{mg} / \mathrm{L})\end{array}$ & $\begin{array}{c}\text { \% Reduction } \\
\text { Power }\end{array}$ & $\begin{array}{c}\mathrm{IC}_{50} \\
(\mathrm{mg} / \mathrm{L})\end{array}$ \\
\hline \multirow{3}{*}{ BHT } & 0.25 & $15.71 \pm 0.46$ & \\
& 0.5 & $33.53 \pm 0.28$ & $0.73 \pm 0.02$ \\
& 0.75 & $51.00 \pm 0.77$ & \\
Ethanolic Extract & 4 & $25.17 \pm 1.44$ & \\
& 8 & $35.10 \pm 0.27$ & $18.43 \pm 0.20$ \\
& 12 & $41.49 \pm 0.44$ & \\
& 16 & $45.27 \pm 0.38$ & \\
\end{tabular}

Table 3: Results of Alpha-Glucosidase Enzyme Activity Inhibition Test.

\begin{tabular}{lccc}
\hline Sample & $\begin{array}{c}\text { Concentration } \\
(\mathrm{mg} / \mathrm{L})\end{array}$ & \% Inhibition & $\begin{array}{c}\mathrm{IC}_{50} \\
(\mathrm{mg} / \mathrm{L})\end{array}$ \\
\hline 30 & $35.31 \pm 0.07$ & \\
Acarbose & 60 & $41.50 \pm 0.27$ & \\
& 90 & $47.23 \pm 0.15$ & $98.67 \pm 0.13$ \\
& 120 & $56.53 \pm 0.15$ & \\
& 150 & $60.11 \pm 0.15$ & \\
Ethanolic Extract & 10 & $48.22 \pm 0.39$ & \\
& 25 & $59.89 \pm, 1.14$ & $10.95 \pm 0.28$ \\
& 50 & $70.65 \pm 0.1$ & \\
& 100 & $74.95 \pm 0.03$ &
\end{tabular}
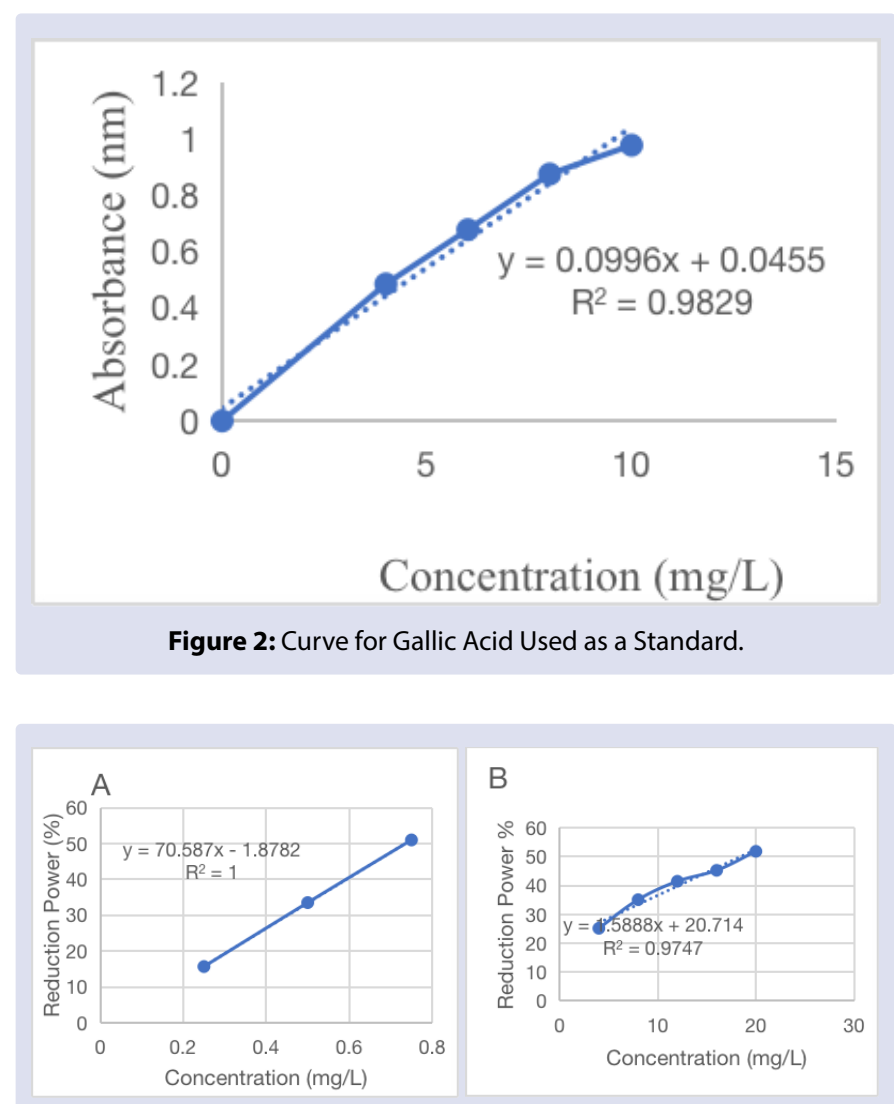

Figure 3: Cupric Reducing Ability of (A) BHT and (B) R. nasutus Stem Bark Ethanol Extract.
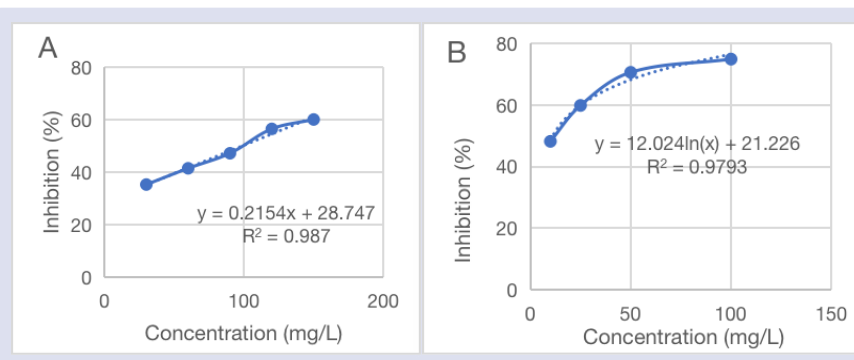

Figure 4: Graph of the Relationship between Concentration and \% Inhibition for IC50 Determination. (a) Acarbose and (b) R. nasutus Stem Bark Ethanol Extract.

yellow. The absorbance can be read at $450 \mathrm{~nm}$. The absorbance read at a specific wavelength correlates with the concentration of antioxidants in the sample ${ }^{23}$.

The CUPRAC test results are expressed as \% reduction power (Table 2 ), which is then linked to a series of sample or standard concentrations to produce a curve, as shown in Figure 3. The regression equation for BHT and ethanol extract of $R$. nasutus stem bark obtained was $\mathrm{y}=$ $70,587 \mathrm{x}-1.8782$ and $\mathrm{y}=1.5888+20.714$. From this equation, the $\mathrm{IC}_{50}$ value for BHT was $0.73 \pm 0.02 \mathrm{mg} / \mathrm{L}$ and for the ethanol extract of $R$. nasutus stem bark was $18.43 \pm 0.20 \mathrm{mg} / \mathrm{L}$. This $\mathrm{IC}_{50}$ value describes each sample's antioxidant capacity at the time of the reducing \% value of 50 In general, BHT has a better reducing ability to $\mathrm{Cu}^{2+}$ than the ethanol extract of $R$. nasutus stem bark, but the reduction power of ethanol extract is included. In the very strong category because the $\mathrm{IC}_{50}$ value is less than $50 \mathrm{mg} / \mathrm{L}^{34}$.

The results showed that the ethanol extract of the stem bark of $R$. nasutus has the potential as an alternative source of natural antioxidants. The 
reaction mechanism that occurs in the CUPRAC method involves oxidation and reduction reactions. This mechanism correlates with the redox properties of antioxidant compounds in plants. This property plays an important role in trapping and neutralizing free radicals, quenching singlet and triplet oxygen, or decomposing peroxides ${ }^{35,36}$.

\section{Potential Inhibition of Alpha-Glucosidase Enzyme Activity in Ethanol Extract}

Based on the alpha-glucosidase enzyme activity inhibition test, acarbose solutions at concentrations of $30,60,90,120$, and $150 \mathrm{mg} /$ $\mathrm{L}$ had \% inhibition of $35.31 \pm 0.07,41.50 \pm 0.27,47.23 \pm 0.15,56.53 \pm 0.15$, and $60.11 \pm 0.15$, respectively. The ethanol extract of $R$. nasutus stem bark at concentrations of $10,25,50$, and $100 \mathrm{mg} / \mathrm{L}$ had \% inhibition of $48.22 \pm 0.39,59.89 \pm 1.14,70.65 \pm 0.1$, and $74.95 \pm 0.03$, respectively (Table $3)$. The relationship between the concentration and \% inhibition of acarbose and ethanol extract is made in graphical form (Figure 4), so that the regression equations are $y=0.2154 x+28.747$ and $y=12.024 \ln x$ +21.226 , respectively. From this equation, the $\mathrm{IC}_{50}$ value for acarbose was $98.67 \pm 0.13 \mathrm{mg} / \mathrm{L}$ and for the ethanol extract of $R$. nasutus stem bark was $10.95 \pm 0.28 \mathrm{mg} / \mathrm{L}$.

Based on these data, the ethanol extract of $R$. nasutus stem bark has higher alpha-glucosidase enzyme inhibiting activity than acarbose standard. The total phenolic data results, phytochemical screening, antioxidant activity tests, and alpha-glucosidase inhibitory activity tests were related to one another. The antioxidant and antidiabetic properties of the stem bark ethanol extract are related to the presence of phenolic groups that can donate hydrogen atoms to free radicals to become less reactive. Phenolic compounds can also act as competitive inhibitors of carbohydrate digesting enzymes (alpha-glucosidase enzymes) through hydrophobic interactions. These carbohydrates are not quickly hydrolyzed into glucose molecules ${ }^{10}$.

\section{CONCLUSION}

The crude ethanol extract of $R$. nasutus stem bark obtained from the UAE process was $7.4896 \mathrm{~g}$ with a yield of $4.99 \%$. The bark extract's total phenolic content was $677.3343 \pm 0.0007 \mathrm{mg}$ GAE / g sample, the antioxidant activity test using the CUPRAC method gave an $\mathrm{IC}_{50}$ value of $18.43 \pm 0.20 \mathrm{mg} / \mathrm{L}$. The presence of phenolic compounds is thought to have a role in high antioxidant activity. Also, the ethanol extract of stem bark has an increased ability to inhibit the alpha-glucosidase enzyme activity with an $\mathrm{IC}_{50}$ value of $10.95 \pm 0.28 \mathrm{mg} / \mathrm{L}$. It can be concluded that the ethanol extract of the stem bark of $R$. nasutus from the UAE has the potential as a source of antioxidants and antidiabetic.

\section{ACKNOWLEDGEMENT}

This work was supported by Doctoral Dissertation Research 2021 [Nomor: NKB-295/UN2.RST/HKP.05.00/] from Ministry of Research and Technology / National Research and Innovation Agency, Indonesia.

\section{CONFLICTS OF INTEREST}

The authors declare that they have no conflict of interest.

\section{REFERENCES}

1. Edeoga HO, Okwu DE, Mbaebie BO, Phytochemical Constituents of Some Nigerian Medicinal Plants, African Journal of Biotechnology, 2005; 4(7): 685-688.

2. Chan M. Global Report on Diabetes. Vol. 58. World Health Organization; Geneva; 2014.

3. Cho NH, Shaw JE, Karuranga S, et al, IDF Diabetes Atlas: Global Estimates of Diabetes Prevalence for 2017 and Projections for 2045, Diabetes Research and Clinical Practice, 2018; 138: 271-281.
4. Dipiro JT, Talbert RL, Yee GC, Matzke GR, Wells BG, Posey LM. Pharmacoterapy: A Phatophysiologic Approach. McGraw-Hill Educational Medical; New York; 2017.

5. Hasan SMMMA, Khan MI, Umar BU, Sadeque M, Comparative Study of the Effect of Ethanolic Extract of Swietenia mahagoni Seeds with Rosiglitazone on Experimentally Induced Diabetes Mellitus in Rats, Bangladesh Medical Research Council Bulletin, 2013; 39: 6-10.

6. Playford RJ, Pither C, Gao R, Middleton SJ, Use of the Alpha Glucosidase Inhibitor Acarbose in Patients with 'Middleton Syndrome: Normal Gastric Anatomy but with Accelerated Gastric Emptying Causing Postprandial Reactive Hypoglycemia and Diarrhea, Canadian Journal of Gastroenterology, 2013; 27(7): 403-404.

7. Mata R, Cristians S, Escandón-Rivera S, Juárez-Reyes K, RiveroCruz I, Mexican Antidiabetic Herbs: Valuable Sources of Inhibitors of a-Glucosidases, Journal of Natural Products, 2013; 76(3): 468-483.

8. Hanafi, Irawan C, Rochaeni H, Sulistiawaty L, Roziafanto AN, Supriyono, Phytochemical Screening, LC-MS Studies and Antidiabetic Potential of Methanol Extracts of Seed Shells of Archidendron bubalinum (Jack) I.C. Nielson (Julang Jaling) from Lampung, Indonesia, Pharmacognosy Journal, 2018; 10(6): s77-s82.

9. Sukiman M, Margaretha JA, Irawan C, Hanafi, Sulistiawaty L, Evaluation of Antidiabetes Activity of Matoa Seed Extract (Pometia pinnata) Using Enzym a-Glucosidase, The Pharma Innovation Journal, 2018; 7(5): 10-12

10. Patil P, Mandal S, Tomar SK, Anand S, Food Protein-Derived Bioactive Peptides in Management of Type 2 Diabetes. European Journal of Nutrition. 2015; 54(6): 863-880.

11. Maarisit W, Yamazaki $H$, Abdjul DB, Takahashi O, Kirikoshi $R$, Namikoshia M, A New Pyranonaphtoquinone Derivative, 4-oxorhinacanthin A, from Roots of Indonesian Rhinacanthus nasutus, Chemical and Pharmaceutical Bulletin. 2017; 65(6), 586-588.

12. Bukke S, Raghu PS, Sailaja G, Kedam TR, The Study on Morphological, Phytochemical and Pharmacological Aspects of Rhinacanthus nasutus. (L) Kurz (A Review), Journal of Applied Pharmaceutical Science, 2011; 1(8): 26-32.

13. Wu TS, Tien HJ, Yeh MY, Lee KH, Isolation and Cytotoxicity of Rhinacanthin-A and -B, Two Naphthoquinones, from Rhinacanthus nasutus, Phytochemistry, 1988; 27(12): 3787-3788

14. Tewtrakul $S$, Tansakul $P$, Panichayupakaranant $P$ Anti-Allergic Principles of Rhinacanthus nasutus Leaves, Phytomedicine. 2009; 16(10): 29-34.

15. Siripong P, Kanokmedakul K, Piyaviriyagul S, et al, Antiproliferative Napthaquinone Esters from Rhinacanthus Nasutus Kurz. Roots on Various Cancer Cells, Journal of Traditional Medicines, 2006; 23: 166-172.

16. Shah MA, Khalil R, Ul-Haq Z, Panichayupakaranant P, $\alpha-$ Glucosidase Inhibitory Effect of Rhinacanthins-Rich Extract from Rhinacanthus nasutus Leaf and Synergistic Effect in Combination with Acarbose, Journal of Functional Foods, 2017; 36: 325-331.

17. Bonfigle M, Godoy E, Reinheimer MA, Scenn, NJ, Comparison between Conventional and Ultrasound-Assisted Techniques for Extraction of Anthocyanins from Grape Pomace. Journal of Food Enginering. 2017; 207: 56-72.

18. Bukke S, Mallepogu V, Kedam TR, Phytochemical Analysis, InVitro Antioxidant Activity and Proximate Analysis on Rhinacanthus nasutus (L) Kurz Leaf, Indian Journal of Applied Research, 2013; 3(5): 33-35.

19. Wang $L$, Weller $C L$, Recent Advances in Extraction of Nutraceuticals from Plants, Trends in Food Science \& Technology, 2006; 17: 300-312.

20. Azmir J, Zainudin ISM, Rahman MM, Sharif KM, Mohamed A, Sahena F, Techniques for Extraction of Bioactive Compounds from Plant Materials: A Review, Journal of Food Engineering, 2013; 117: 426-436. 
21. Rostagno MA, Palma M, Barroso CG, Ultrasound Assisted Extraction of Soy Isofiflavones, Journal of Chromatography A. 2003; 1012: 119-128.

22. Singleton $V L$, Orthofer R, Lamuela-Raventos RM, Analysis of Total Phenols and other Oxidation Substrates and Antioxidants by means of Folin-Ciocalteu Reagent, Methods Enzymmol, 1999; 299: 152-179.

23. Apak R, Guclu K, Demirata B, et al, Comparative Evaluation of Various Total Antioxidant Capacity Assay Applied to Phenolic Compounds with the CUPRAC Assay, Molecules, 2007; 12: 1496-1547.

24. Budiarso FS, Elya $B$, Hanafi M, Forestranla RC, The Potential of Stem Bark of Kayu Sarampa (Xylocarpus moluccensis (Lam.) M. Roen) as $\alpha$-Glucosidase Inhibitor, Pharmacognosy Journal, 2020; 12(6): 1368-1376

25. Garcia-Salas P, Morales-Soto A, Segura-Carretero A, FernandezGutierrez A, Phenolic-Compound-Extraction Systems for Fruit and Vegetable Samples. Molecules, 2010; 15: 8813-8826.

26. Corrales M, Toepflf| S, Butz P, Knorr D, Tauscher B, Extraction of Anthocyanins from Grape by-Products Assisted by Ultrasonics, High Hydrostatic Pressure or Pulsed Electric Fields: A Comparison. Innovative Food Science and Emerging Technologies, 2008; 9: 85-91.

27. Sundang $M$, Nasir S, Sipaut $C$, Othman H, Antioxidant Activity, Phenolic, Flavonoid, and Tannin Content of Piper betle and Leucosyke capitella. Malaysian Journal of Fundamental \& Applied Sciences, 2012; 8(1): 1-6.

28. Sanchez-Rangel JC, Benavides J, Heredia JB, Cisneros-Zevallos L, Jacobo-Velasquez DA, The Folin-Ciocalteu Assay Revisited: Improvement of its Specificity for Total Phenolic Content Determination, Analytical Methods. 2013; 5(21): 5990-5999.
29. Lee KW, Kim YJ, Lee HJ, Lee CY, Cocoa Has More Phenolic Phytochemical and A Higher Antioxidant Capacity than Teas and Red Wine, Journal of Agricultural and Food Chemistry, 2003; 51 (25): 7292-7295.

30. Huang D, Ou, B, Prior RL, The Chemistry Behind Antioxidant Capacity Assays, Journal of Agricultural and Food Chemistry, 2005: 53: 1841-1856.

31. Mathew S, Abraham TE, Zakaria ZA, Reactivity of Phenolic Compounds Towards Free Radicals Under inVitro Conditions, Journal of Food Science and Technology, 2015; 52(9): 5790-5798.

32. Phaniendra A, Jestadi DB, Periyasamy L, Free Radicals: Properties, Sources, Targets, and Their Implication in Various Diseases, 2015; 30(1): 11-26.

33. Prior RL, Wu X, Schaich K, Standardized Methods for the Determination of Antioxidant Capacity and Phenolics in Food and Dietary Supplements, Journal of Agricultural and Food Chemistry, 2005; 53: 4290-4302.

34. Jun M, Fu HY, Hong J, Wan X, Yang CS, Ho CT, Comparison of Antioxidant Activities of Isoflavones from Kudzu Root (Pueraria lobate Ohwi), Journal of Food Science, 2006; 68(6); 2117-2122.

35. Nurliyana R, Zahir IS, Suleiman KM, Aisyah MR, Rahim K, Antioxidant Study of Pulps and Peels of Dragon Fruits: A Comparative Study, International Food Research Journal, 2010; 17: 367-375.

36. Mishra SL, Sinhamahapatra PK, Nayak A, Das R, Sannigrahi, In Vitro Antioxidant Potential of Parts of Oroxylum indicum: A Coparative Study, Indian Journal of Pharaceutical Sciences, 2010; 72(2): 267-269. 


\section{GRAPHICAL ABSTRACT}

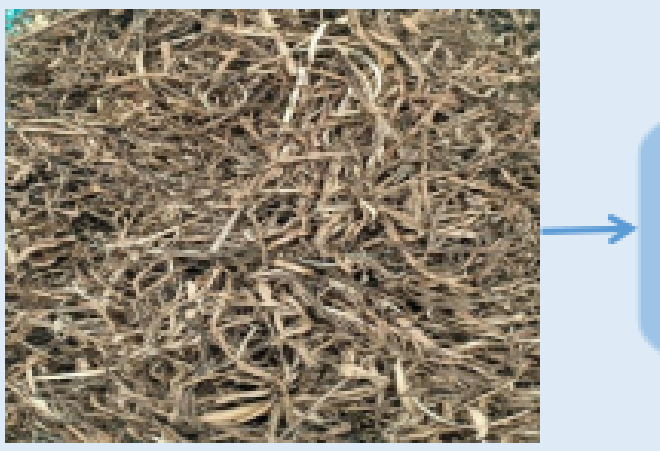

\section{Simplicia Set up and}

Extraction with UAE

Methods using Ethanolic

Solvent
The crude ethanol extract of $R$. nasutus stem bark of $7.4896 \mathrm{~g}$ with a yield of $4.99 \%$.

The Stem Bark Samples of $R$. nasutus

The total phenol content in the stem bark of $R$. nasutus obtained from this equation was $677.3343 \pm 0.0007 \mathrm{mg}$ $\mathrm{GAE} / \mathrm{g}$ of the sample.
The IC $_{50}$ value for BHT was $0.73 \pm 0.02 \mathrm{mg} / \mathrm{L}$ and for the ethanol extract of $R$. nasutus stem bark was $18.43 \pm 0.20 \mathrm{mg} / \mathrm{L}$.

Conclusion: The ethanol extract of the stem bark of $R$. nasutus from the UAE has the potential as a source of antioxidants and inhibitor of alphaglucosidase enzyme activity. 


\section{ABOUT AUTHORS}
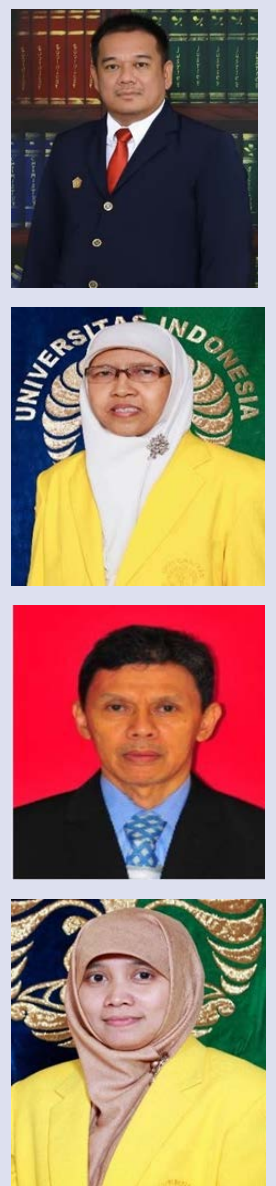

Candra Irawan is a Doctoral Pharmacy Student at the Faculty of Pharmacy, Universitas Indonesia, Kampus UI Depok, West Java 16424, Indonesia and Lecturer at the Politeknik AKA Bogor. He has research experience in the field of Phytochemistry and Natural Product.

Berna Elya is a Professor and Lecturer at the Faculty of Pharmacy, Universitas Indonesia, Kampus UI Depok, West Java 16424, Indonesia. She develops works in the area of Pharmacognosy, Phytochemistry, and Natural Product.

Muhammad Hanafi is a Researcher Professor at the Research Center for Chemistry, Indonesian Institute of Sciences, PUSPITEK area, Serpong, South Tanggerang, Banten, Indonesia and Lecturer at the Faculty of Pharmacy, Universitas Pancasila, Srengseng Sawah, Jakarta, Indonesia. He has research experience in the field of Natural Product.

Fadlina Chany Saputri is a Associate Professor and Lecture at Departemen of Pharmacology, Faculty of Pharmacy, Universitas Indonesia. Kampus UI Depok, West Java 16424, Indonesia.. She has experience in the area of pharmacology and herbal medicine, working in drug discovery for metabolic disorder and degenerative diseases (such as diabetes mellitus, hypertension, hyperlipidemia, atheroschlerosis, etc).

Cite this article: Irawan C, Elya B, Hanafi M, Saputri FC. Application of Ultrasound-Assisted Extraction on the Stem Bark of Rhinachantus Nasutus (L.) Kurz, Total Phenolic, and Its Potential as Antioxidant and Inhibitor of Alpha-Glucosidase Enzyme Activity. Pharmacogn J. 2021;13(5): 1297-1303. 